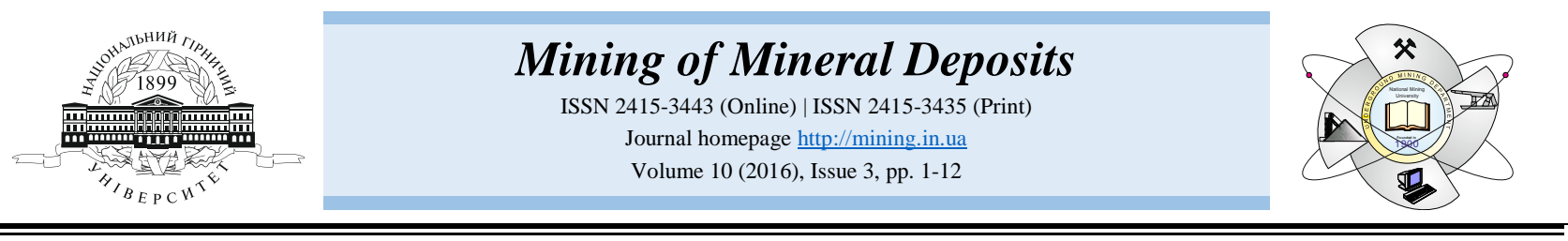

UDC 622'112:518.12(076.2)

http://dx.doi.org/10.15407/mining10.03.001

\title{
NUMERICAL METHODS OF GEOMECHANICS TASKS SOLUTION DURING COAL DEPOSITS' DEVELOPMENT
}

\author{
V. Bondarenko ${ }^{1 *}$, M. Hardygora ${ }^{2}$, H. Symanovych ${ }^{1}$, V. Sotskov ${ }^{1}$, V. Snihur ${ }^{3}$ \\ ${ }^{1}$ Underground Mining Department, National Mining University, Dnipropetrovsk, Ukraine \\ ${ }^{2}$ Faculty of Geoengineering, Mining and Geology, Wroclaw University of Technology, Wroclaw, Poland \\ ${ }^{3}$ MA "Ternivske" PJSC "DTEK Pavlohradvuhillia", Pavlohrad, Ukraine \\ *Corresponding author: e-mail v_domna@yahoo.com, tel. +380562471472, fax: +380563742184
}

\section{ЧИСЕЛЬНІ МЕТОДИ РОЗВ'ЯЗАННЯ ЗАДАЧ ГЕОМЕХАНІКИ ПРИ РОЗРОБЦІ ВУГІЛЬНИХ РОДОВИЩ}

\author{
В. Бондаренко ${ }^{1 *}$, М. Хардигора ${ }^{2}$, Г. Симанович ${ }^{1}$, В. Соцков ${ }^{1}$, В. Снігур ${ }^{3}$ \\ ${ }^{1}$ Кафедра підземної розробки родовищ, Національний гірничий університет, Дніпропетровськ, Україна \\ ${ }^{2}$ Факультет геоінженерії, гірництва і геологї̈, Вроилавський технологічний університет, Вроилав, Польща \\ ${ }^{3}$ ШУ “Тернівське” ПАТ “ДТЕК Павлоградвугілля”, Павлоград, Україна \\ *Відповідальний автор: e-mail ﹎_domna@yahoo.com, тел. +380562471472, факс: +380563742184
}

\begin{abstract}
Purpose. Generalization of numerical modeling of geomechanical processes in the vicinity of mine workings by finite elements method and making recommendations for substantiation of suitable construction and behavior of rock massif physical model.
\end{abstract}

Methods. Software packages SolidWorks Simulation (COSMOS/M) and ANSYS are used for geomechanical tasks solution.

Findings. Solutions of geomechanical tasks dealing with topical issues of estimating stress-strain state of rock massif around underground workings of different functions are given. Data on the rock massif stress-strain state are received and recommendations on adequate and authentic reflection of its structural peculiarities (stratification and fracturing) are made. Physical model of rock condition (elastic, elastic-plastic, rheological diagrams and complete diagram of deformation taking into account weakening and fracturing) is presented.

Originality. New data about the mechanism of movement processes of coal-bearing massif around mine workings considering stratification and cracks content, limit and out-of-limit deflection state in separate areas, and also the impact of rheological rock properties are received.

Practical implications. Complex of geomechanical tasks solutions allow to increase credibility of rock pressure manifestations prediction and substantiate technical solutions for effective and safe operations at coal mines.

Keywords: rock massif, underground working, finite elements method, stresses, deformations, stratification, cracks content, physical model, rock pressure

\section{INTRODUCTION}

Numerical solutions of applied tasks have always been the matter of concern for the best mathematicians. Obtaining mathematical description of a phenomenon or process and their research resulted in the birth of a separate field in applied mathematics - mathematical physics. Further, through development and improvement of various tasks solution, this direction of the theoretical analysis was transformed into a new modern technology and methodology of theoretical research which has received the name of computing experiment. Computing experiment is based on mathematical modeling, its theoretical base being applied mathematics, and technical base - powerful computing machines.
When solving tasks of geomechanics, we constantly face the problem of computing systems with a complex geometrical configuration and irregular physical structure. The massif and its rocks have a great number of characteristics which can be taken into account only by finitedifference schemes of calculations during mathematical modeling. Nowadays, the finite elements method (FEM) (Gallager, 1984) has become the standard de facto in solution of geomechanical tasks. However, when solving complex geomechanical tasks dealing with multi-factor character of rock mechanical properties, heterogeneity of massif structure and geometrical parameters of a mine-technical object, it is possible to combine FEM with methods of boundary and discrete elements (Samarskiy, 1989) to ob- 
tain a more reliable solution. The main complexity of such combination application consists in objective reflection of physical essence of the process on the border of model elements conjugation which are investigated by various finite-difference methods.

SolidWorks Simulation (COSMOS/M), FLAC 2D/3D, ABAQUS and ANSYS are usually applied for the solution of geomechanics problems. Nowadays, ANSYS (Chigarev, Kravchuk, \& Smalyuk, 2004) has the widest opportunities for modeling materials, conditions of objects' interaction, solutions of nonlinear tasks and problems of destruction mechanics. Also this software is distinguished by the high level of computing algorithms realization for various conditions of the massif behavior and other features of modeling.

FEM allows to describe a continuous quantity by the model that consists of separate areas (Gallager, 1984; Zienkiewicz, Taylor, \& Zhu, 2005). The developed theoretical fundamentals of creating a discrete model of a continuous quantity (Sekulovich, 1993) involve a number of consecutive actions with finitesimal determination of the design parameter values inside the area under study. It is proved (Zenkevich \& Morgan, 1986) that FEM can be considered as the general method of numerical solution for various types of differential equations including problems of geomechanics where establishment of areas of limit and out-of-limit state of a massif according to the most used criteria of destruction is very important (Matvienko, 2006).

The solution of geomechanics tasks boils down to the following main stages:

- generalized problem definition (solution type, a general view of the model, considered loadings, etc.);

- creation of the model geometry suitable for usage in FEM;

- creation of the final elements grid for the constructed geometry;

- application of boundary conditions to the geometrical model (fixing on the boundary or boundary loadings);

- numerical solution of equation system;

- analysis of the received results.

Peculiarities of geomechanical problems solution can be divided into three main groups (Kuznetsov, Ardashev, \& Filatov, 1987):

- taking into account massif structure (its lithotypes significantly differ in mechanical properties); existence of weakening surfaces both on planes and inside any rock layer; loss of bonding on weakening surfaces; natural fracturing systems of rocks together with influence of other weakening factors;

- considering not only elastic plastic state, but also so-called stages of rock weakening and loosening in certain areas of the massif; in some cases, to increase the model adequacy it is necessary to reflect large-scale geomechanical processes of underworked strata movement accompanied by the formation of collapsed rock zones with joint-block displacement (artificial fracturing);

- geomechanical processes in rock massif depend upon relative position of mine workings; therefore, it is necessary to take into account their interaction, in view of time and space location parameters change in the course of mining operations; geomechanical processes in the massif and its interactions with underground constructions develop in time which makes it reasonable to apply rheological approach to solution of some tasks.
In solving geomechanical problems, not only peculiarities of the massif structure and behavior are important but also adequate account of constructive and technological features of underground workings' supporting facilities, mechanical properties of fixturing materials (including limit state) and the modes of their interaction with surrounding marginal rocks. The above mentioned features of statement and solution of geomechanical tasks are more or less reflected in the modern research on the basis of FEM.

A great number of tasks to solve are focused on studying specifics of stress-strain state (SSS) of the massif (for instance, Prusek, 2010; Manoj, 2010; Yu, Kong, Niu, Zhu, \& Jing, 2013; Coggan, Gao, Stead, \& Elmo, 2012), the choice of technological parameters for mineral deposits' mining (Zhang, Zhang, Hou, Wu, \& Zhou, 2014; Shi, Liu, \& Wang, 2015) and improvement of constructive schemes of mine workings support, including resourcesaving ways of strengthening the marginal massif by anchor support (Manoj, 2010; Yu, Kong, Niu, Zhu, \& Jing, 2013; Coggan, Gao, Stead, \& Elmo, 2012; Garg \& Jaiswal, 2015; Franklin, Fraley, \& Burnham, 1974).

\section{STRATIFICATION AND FRACTURING FACTORS IN MODELING ROCK MASSIF BEHAVIOR}

Bearing in mind the above peculiarities of geomechanical tasks solution, let us consider some research results obtained at the Underground Mining Department of the National Mining University which are aimed at solving problems of increasing stability of underground mine workings.

Taking as the example in-seam mine working support, we will analyse aspects of modeling stratification and fracturing of the surrounding massif. Stratification substantially changes distribution of stresses both in the vicinity of a working contour, and in the zones adjoining to the borders of rock layers. At the same time, the degree of stratification impact on stresses fields for various components can alter from 10 to $270 \%$ (Symanovych, Ganushevych, \& Chervatyuk, 2010; Kovalevska, Illiashov, Fomychov, \& Chervatuk, 2012; Bondarenko, Kovalevs'ka, \& Fomychov, 2012).

For descriptive reasons, let us analyze diagrams of stresses intensity $\sigma$ for two shapes of cross-section of in-seam mine working (Fig. 1). Changes of the field $\sigma$ in both cases are considerable not only around the mine working, but also on the seam surface. Besides, the less power of lithotype, the more pronounced the changes.

Stratification in calculation model influences separate components of stresses differently, even when solving rather simple tasks. For instance, we will analyze the influence of stratification on distribution of the horizontal $\sigma$ and vertical stresses $\sigma$, received as a result of assesing stability of a single in-seam working (Fig. 2). Isolines have a pronounced intermittent nature: alteration of stresses gradient zones is observed on the boundaries of rock layers, in some areas with a change of sign. This indicates that in certain conditions, if we take stratification into account, the contribution of horizontal stresses to the limit state of rocks can surpass the influence of vertical stresses considerably. Therefore, rock pressure cannot be treated as a linear function directly proportional to the weight of a rock pillar over the mine working. 
(a)

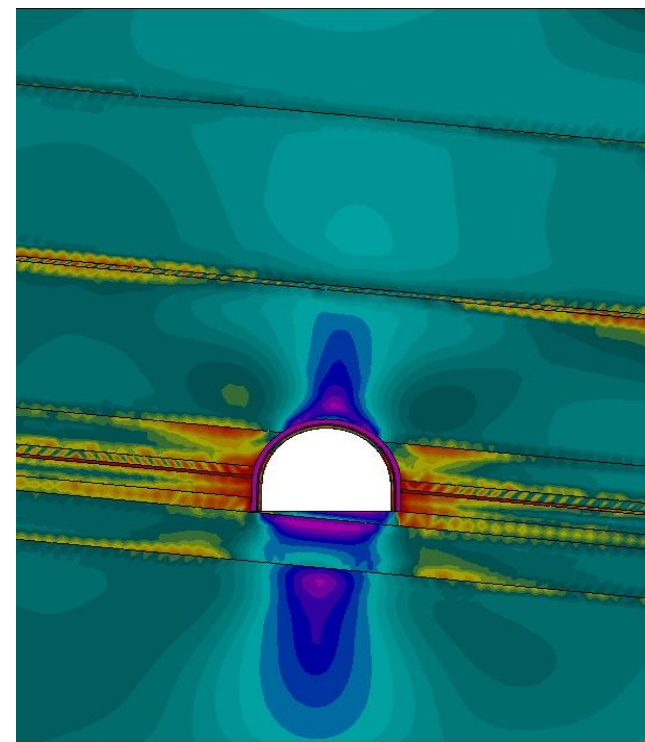

(b)

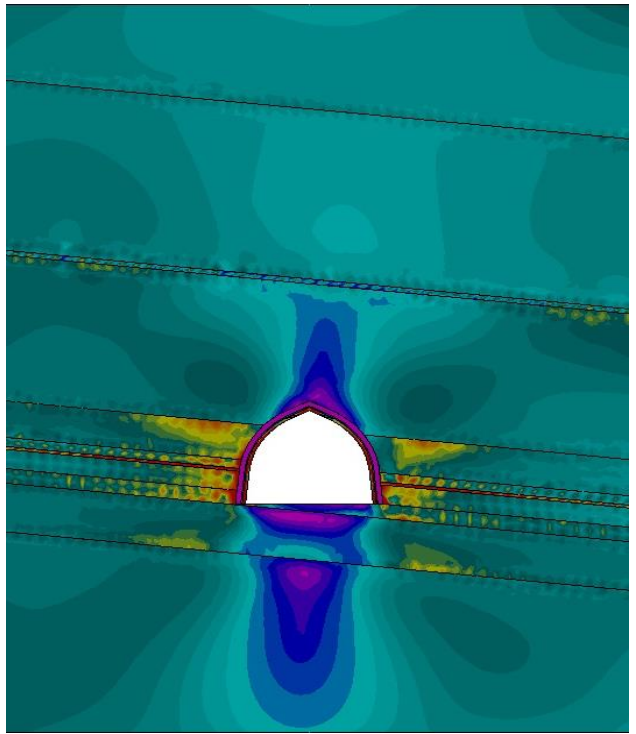

Figure 1. Distribution of stresses $\sigma$ intensity in stratified massif nearby in-seam mine working with different dome shapes: (a) support MYS-A3 (Mechanized Yielding Support); (b) support BTS-2 (Buckled Triangled Support)

(a)

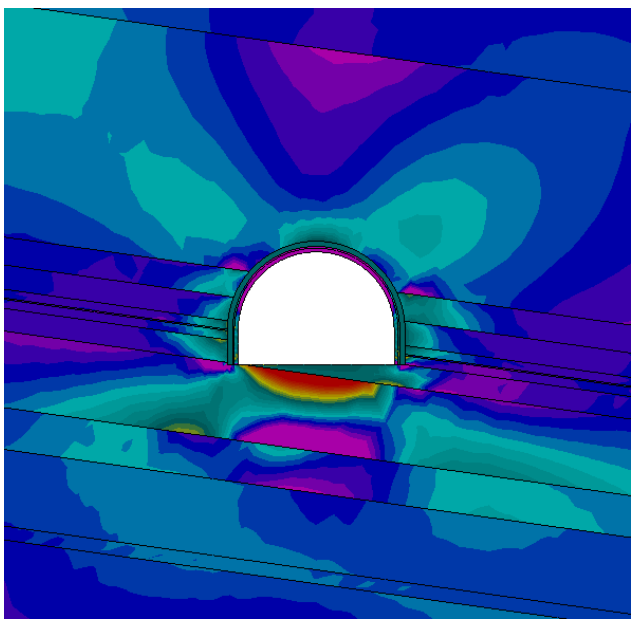

(b)

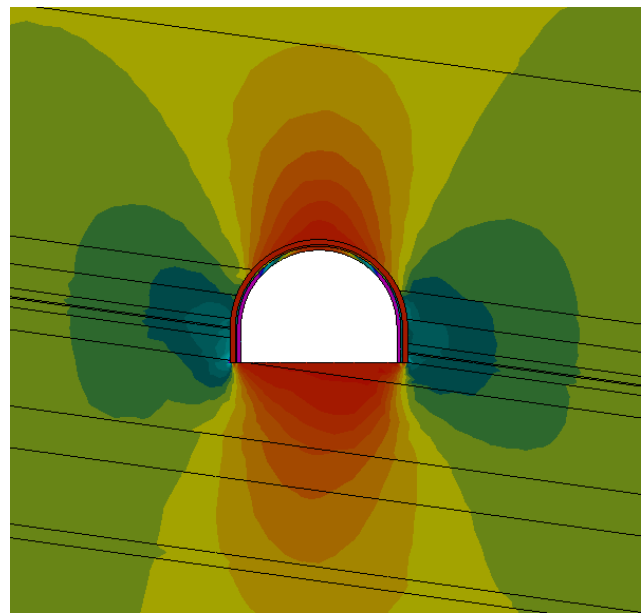

Figure 2. Distribution of horizontal (a) and vertical (b) stresses in stratified massif nearby in-seam mine working

Stratification influences the diagram of vertical stresses absolutely in a different way: formation of compressive and tensile zones practically does not depend upon the structure of rock massif. Minor change of such zones outlines does not lead to stresses growth in absolute values within their limits.

Moreover, rock layers have various thickness and mechanical properties, that is why it is necessary to change conditions of contacts on the seam planes to increase adequacy of the received results. Generally, we can distinguish three types of such contacts: contact of a rigid type, contact with layers' slipping and the contact determined by friction force. Application of any type of contact can lead to qualitative and quantitative changes of stresses distribution pattern.

So, diagrams of stresses intensity $\sigma$ (Fig. 1) show clearly how the choice of contact can produce an impact taking into account friction for all boundaries of lithologic differences. Diagrams of $\sigma$ contain areas where "rip- ples" in the stresses field are clearly visible. This effect is caused by specifics of the numerical methods applied for determination of equilibrium condition of the computational scheme on the contacts of its separate elements. This effect has strictly localized zones of manifestation which completely coincides with finite elements whose separate units belong to the contacting surface. Appearance of this effect in most cases testifies that the computational area is on the boundary of transition from condition of static balance to conditions of dynamic state. If the rock layer thickness is one or more orders less than width of the model itself, all rock volume gets involved in this phenomenon. The described peculiarity is often used for modeling conditions for contacts with friction force when a pseudo-layer with special deformation characteristics is placed between "real" lithotypes. It allows to emulate interaction of separate elements of the model in realistic conditions of rigid contact and at the same time not to go beyond static balance of the whole system. 
Other conditions of adjacent lithotypes' contact are presented in diagrams of stresses in Figure 3. For a case of rigid contact at a moderate interval of changing layers' mechanical characteristics, the distribution pattern of $\sigma$ substantially coincides with diagram of $\sigma$ for a model that does not take stratification into account. On the contrary, in conditions of layers slipping (violation of grip between them) the pattern of stresses $\sigma$ essentially differs from the model of uniform massif. Only one condition of layers' slipping has completely changed the structure of stresses distribution in the coal seam; the level of $\sigma$ in coal layer has become much higher than that in the

(a)

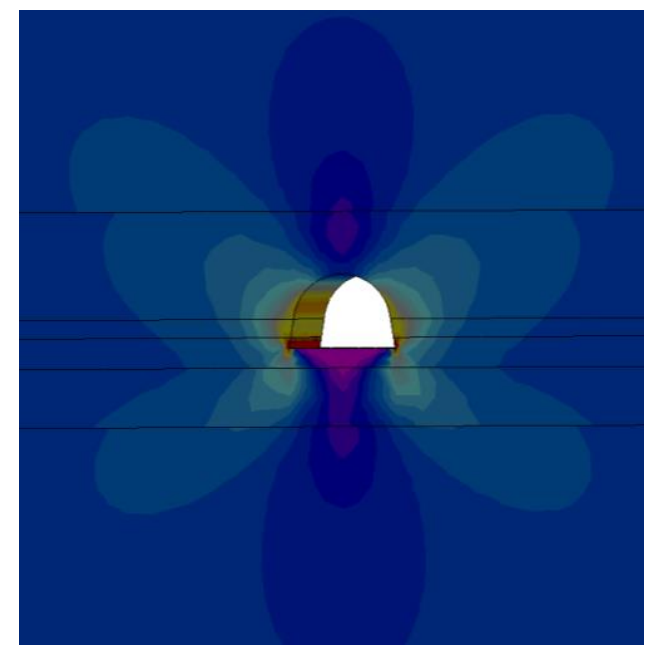

roof and bottom rocks, and its influence on the stability of mine working has sharply increased. Also distribution of $\sigma$ in sides and bottom of mine working has changed resulting in the decrease of their stability.

Main conclusion: it is proved for the first time that modeling of rock massif stratification is insufficient for adequate description of its real state; it is necessary (by way of mine observation and laboratory research) to simulate interaction conditions related to contacts of adjacent lithologic differences, without violating the fundamental principle of static balance of the whole geomechanical system.

(b)

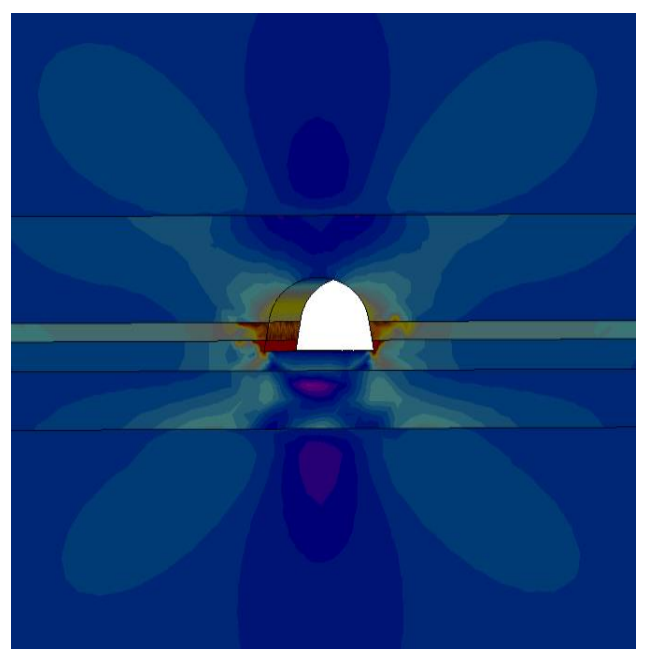

Figure 3. Distribution of stresses intensity $\sigma$ in stratified massif around in-seam mine working for conditions of: (a) rigid contact between lithotypes; (b) slipping over bedding surfaces

Now let us consider the influence of the massif fracturing on stress-strain state (SSS) of geomechanical models. Figure 4 contains examples of distribution of movements and vertical stresses during modeling of fracturing in various computing experiments. Fracturing was considered as a macrocharacteristics for in-seam mine working in the area beyond the zone affected by stoping operations (Fig. 4a). As rock layers of immediate roof and bottom had a pronounced system of cracks focused parallel to the bedding plane and during computing experiment it was necessary to study the influence of this system of cracks on the working contour shifts, we decided to model these violations of continuity as a system of rock benches with thickness equal to the average distance between cracks. The received results have shown sufficient degree of calculation model adequacy in relation to actually observed rock pressure manifestations.

During the computational experiment on detecting rock pressure manifestations specifics after stoping face passage (Fig. 4b), fracturing was treated as microcharacteristics and was modeled considering coefficients that diminish mechanical characteristics of fractured formations. The choice of such approach was defined by parameters of cracks content system and complexity of the calculation model. Firstly, we observed two-three systems of cracks with small average distance between them in rocks of immediate roof and bottom. Modeling of so intensive fracturing leads to significant increase in the level of calculation model complexity and reduces computational stability. Secondly, existence of a large number of elements (rock blocks) which interact in complicated contact conditions, result in manifold increase of calculation time. As a result, additional modeling of fracturing substantially complicates calculation process, and its influence on stresses distribution in calculation area on the whole is rather uniform and is not predominant.

A more detailed analysis of the massif fracturing influence on its state in the vicinity of in-seam mine working was conducted using a real example of a roadway support in the following mine-and-geological conditions: coal seam of average thickness $(m=1.5 \mathrm{~m})$ and small hardness (Protodyakonov scale of hardness $f=1.0-1.5$ ); rocks of immediate roof and bottom with average hardness $f=5-7$; hard rocks of main roof and bottom with hardness $f=9-11$. In spite of the fact that roadway is supported beyond the zone of stoping operations influence, there appeared serious problems with ensuring stability of hard rocks and rocks of average hardness (as early as during mine working drivage) because of intensive fracturing (two mutually perpendicular crack systems with average distance between them $0.1 \mathrm{~m} \leq l_{C} \leq 0.5 \mathrm{~m}$ ) in immediate roof and the lower layer of the main roof. 
(a)

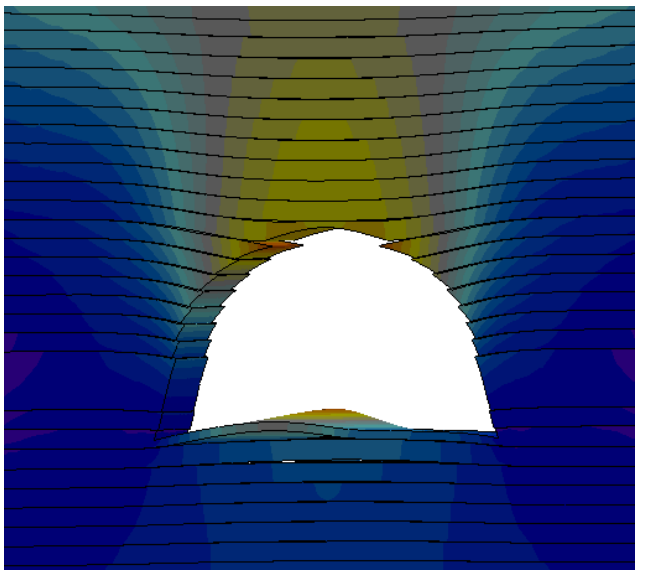

(b)

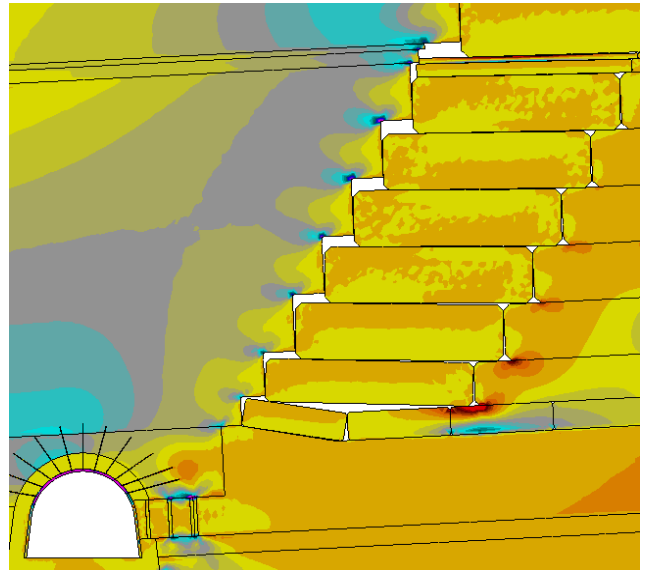

Figure 4. Deformation of massif fracturing around a single in-seam mine working (a) and distribution of horizontal stresses (b) in the massif behind the stoping face during block collapse of roof rocks above the worked-out area

For the analysis of a mine-and-geological situation and substantiation of technological solutions to ensuring stability of in-seam roadway, three groups of experiments have been conducted to compute:

- the real structure of the surrounding massif, but without taking into account its fracturing; such model served as a base for comparing fields of SSS components distribution;

- the same, but taking into account two systems of fracturing as macrocharacteristics at the average distance between cracks $l_{C}=0.5 \mathrm{~m}$;

- the same at $l_{C}=0.3 \mathrm{~m}$.

(a)

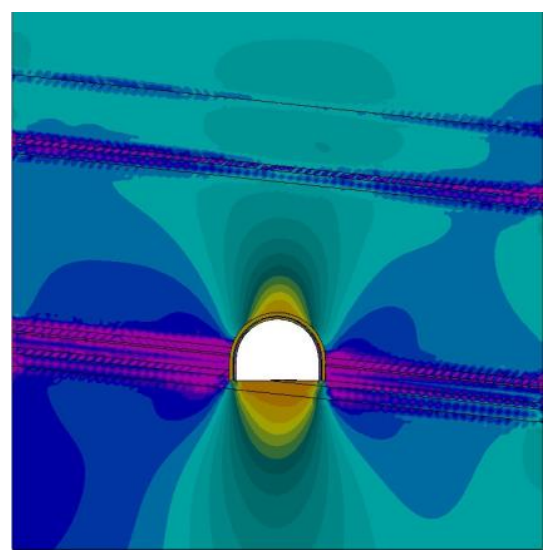

Also an attempt to simulate massif fracturing at $l_{C}=0.1 \mathrm{~m}$ has been made, but computing process was extremely unstable because of a very complicated calculation area.

Figure 5 presents a diagram of vertical stresses $\sigma_{y}$ in the set sequence of calculations performance. At the same time let us pay attention to the parameters change in the three main zones of rock pressure anomalies: areas of unloading in the roof and bottom, area of concentrations $\sigma_{y}$ in the sides of the roadway.

Figure 5. Diagrams of vertical stresses in foliated coal-bearing strata around in-seam roadway without taking into account fracturing (a) and with taking into account the average distance between cracks $l_{c}=0.5 \mathrm{~m}(\mathrm{~b})$ and $l_{c}=0.3 \mathrm{~m}(\mathrm{c})$

If there is no fracturing in the roof of mine working, an unloading zone $\sigma_{y}$ of the dome shape is clearly traced, which to some extent confirms a classical hypothesis of Prof. M.M. Protodyakonov. Let us estimate the sizes of the arch by the criterion of horizontal and vertical compression stresses absence $\left(\sigma_{x, y}=0\right)$ in view of the fact that the massif with intense development of two fracturing systems is not able to resist tensile forces. According to such condition, height of the arch was equal $1.0-1.1 \mathrm{~m}$, and its width $3.2-3.4 \mathrm{~m}$ (Fig. 5a). An abso- (b)

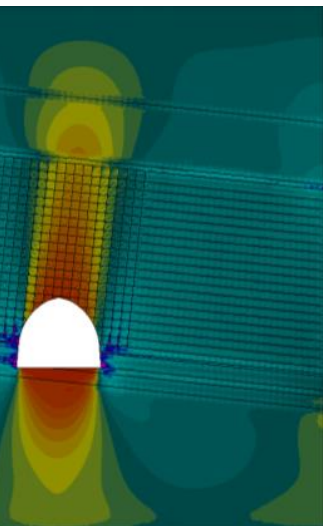

(c)

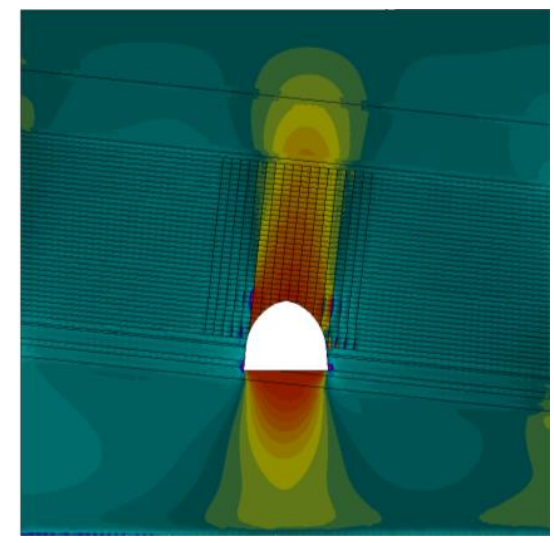

lutely different picture is observed when we consider roof fracturing (Fig. 5c): height of the arch has increased to $7.5 \mathrm{~m}$ at $l_{C}=0.5 \mathrm{~m}$ and to $8.6 \mathrm{~m}$ at $l_{C}=0.3 \mathrm{~m}$; width of the arch has changed not so significantly - to $3.9 \mathrm{~m}$ at $l_{C}=0.5 \mathrm{~m}$ and to $4.8 \mathrm{~m}$ at $l_{C}=0.3 \mathrm{~m}$. These data confirm the manifold growth of unstable roof rock which creates high loading on mine working support in case of collapse, despite placement in the rocks of average and high hardness.

The similar situation characterised by significant increase in depth of unstable rocks area is observed in 
the bottom of roadway that involves active development of such geomechanical event as bottom rocks heaving. On the contrary, originally high (without taking into account fracturing) abutment pressure in mine working sides repeatedly decreases, which is caused by the dominating influence of fractured rocks with very low deformation characteristics.

Thus, in geomechanical models reflecting natural fracturing of the massif at macrolevel, the distribution pattern of SSS components essentially changes, and the main complexity consists in ensuring appropriate stability of computing process which is defined by the computing power of electronic computing machine.

As a result, a new approach has been proposed to searching for a compromise between adequacy of massif fracturing display and possibility of stable conducting of computing experiment, division of modeling natural fracturing technology into macro- and microlevels. The preference is given to geometrical modeling of cracks content systems, i.e. to the situation that exhausts technical capabilities of stable conducting of computing experiment.

\section{SELECTING PHYSICAL MODEL OF THE ROCK MASSIF CONDITION}

As has been noted earlier, besides structural features of a massif in the working vicinity, the degree of reliable reflection of geomechanical processes essentially depends upon the choice of this or that physical behavior model of the rock and bolting constructions: elastic or elastic-plastic condition, the full deformation diagram

(a)

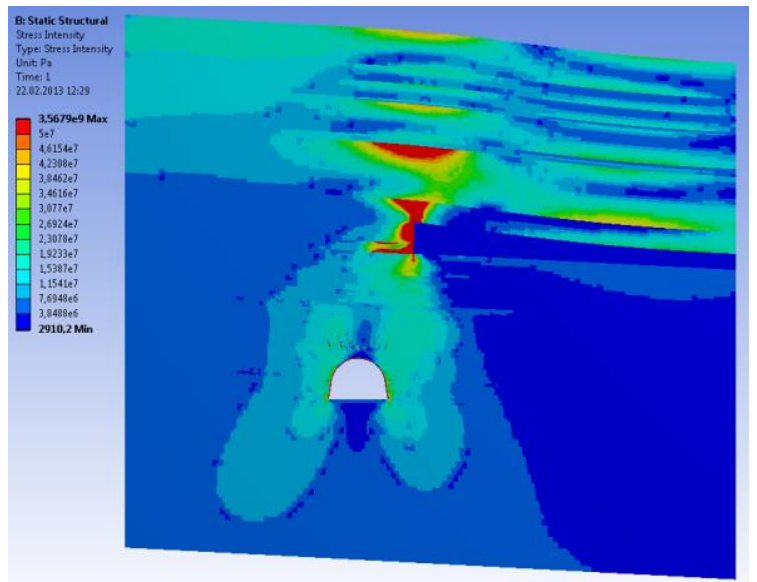

taking into account stages of weakening, fracturing or plastic yielding, considering time factor in rheological models. In each case, it is necessary to reasonably choose the type of the task to solve as unjustified complication of the physical model often leads to failures during computing process.

To distinguish the results of solving elastic and elastic-plastic tasks we will use as an example estimation of stability of overworked drainage ventilating roadway during the period of stoping face passing below. Figure 6 shows the corresponding diagrams of stresses intensity $\sigma$ in foliated coal-bearing massif of poor rocks. Differences (both in terms of quality and quantity) in the nature of stresses intensity distribution in the main zones of calculation area are accurately shown.

Firstly, the active bend of rock layers which during the solution of an elastic task generates a splash in stresses $\sigma 3-5$ times higher than those for an elasticplastic task is traced in the roof of a working seam near stoping face. This physical model reflects more adequately increased deformability of poor layers of the above-the-coal strata which, due to their mechanical properties, "smooth out" anomalies of rock pressure ahead and behind the stoping face. Such situation promotes localization of the main roof active displacement at the height of 5-6 thicknesses of the coal seam (which approximately corresponds to the data obtained from mine supervision) while for elastic model, the intensive bend with weakening of rock layers takes place along all the height of calculation area (up to 24 thicknesses of the coal seam).

(b)

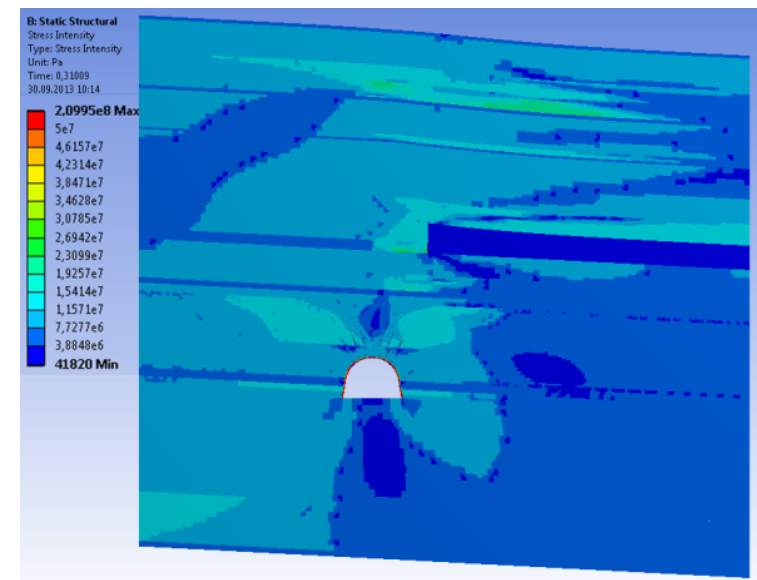

Figure 6. Diagrams of stresses intensity $\sigma$ in foliated massif of poor rocks around overworked drainage roadway during solution of elastic (a) and elastic-plastic (b) tasks

Secondly, in the vicinity of a ventilating drainage roadway placement, the elastic solution of a task gives such rock pressure anomalies which sufficiently $(4-5$ times) exceed similar parameters during solution of elastic-plastic task; concentrations $\sigma$ also decrease on average by $1.5-2$ times.

Differences (for the considered two physical models) in the condition of the surrounding massif certainly affect diagrams of stresses intensity in the elements of bolting system of a ventilating drainage roadway (Fig. 7).
Change of anomalies' parameters of diagram $\sigma$ in elastic-plastic task is distinctly shown as:

- decrease in size and extent of concentrations $\sigma$ action areas in the armature of resin-grouted roof bolts in the roof of mine working and more active loading of side anchors;

- majority of areas along the length of frame support props exiting from a plastic condition;

- increase in loading of the frame beam because of plastic deformations of roof rock layers. 
(a)

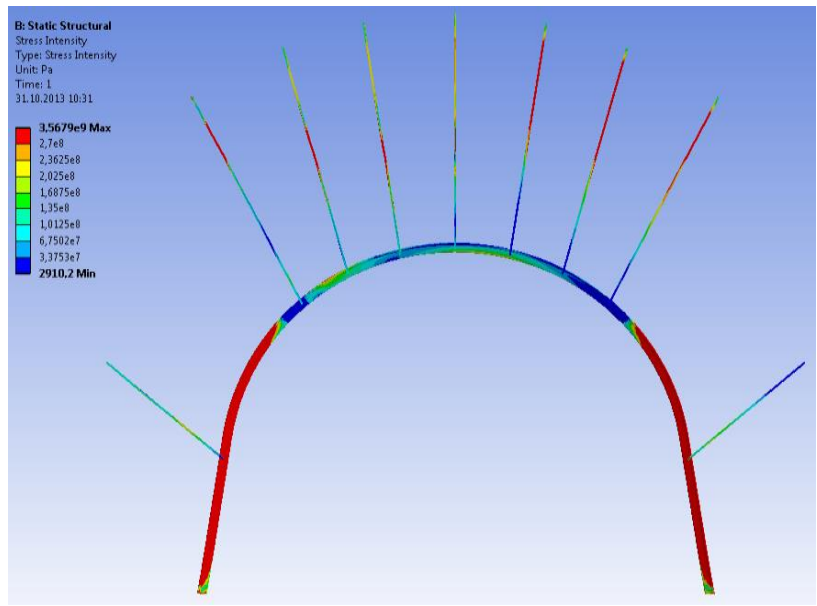

(b)

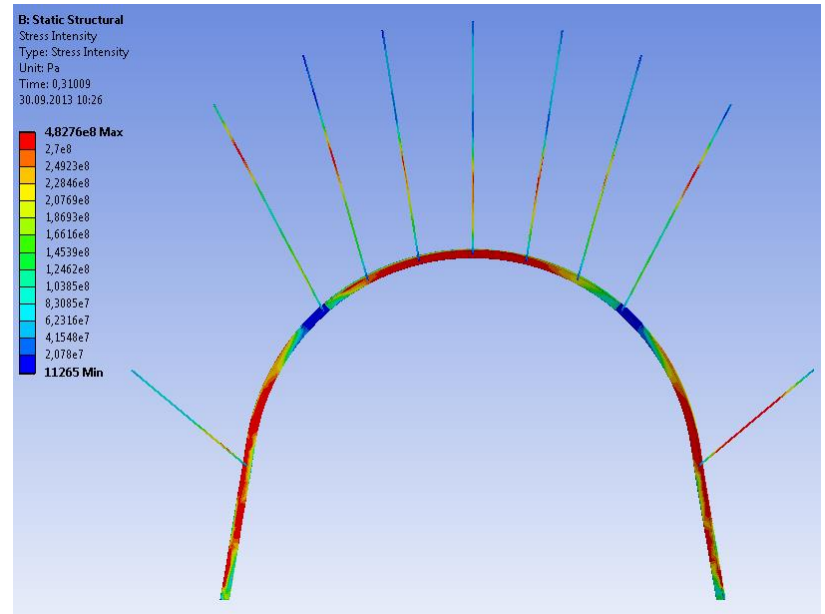

Figure 7. Diagrams of stresses intensity $\sigma$ in elements of bolting system of overworked drainage roadway during solution of elastic (a) and elastic-plastic (b) tasks

Following the results of task solution, we established regularities of change in the state of the surrounding massif and overworked roadway support considering inelastic deformations of this geomechanical system components whose influence changes SSS parameters several times. Thus, substantiation of physical model choice of the investigated geomechanical system is essential for increasing adequacy and reliability of computational experiment results.

It is necessary to reflect processes of weakening and destruction of some lithotypes in certain areas around mine workings which also increases adequacy and reliability of computing experiment results during forecasting of the massif behavior in the wide range of mine-andgeological conditions.

This type of tasks is solved by means of the physical model reflecting the so-called complete diagram of rock deformation from the initial stage of loading to the stage of "ruining" destruction. Usually, such physical model is approximated by three linear areas on the diagram of "stress-relative deformation": the first is an elastic-plastic stage of deformation up to the limit of rock uniaxial compressive strength; the second is rock weakening stage accompanied by decrease in its resistance to compression; the third is the stage of active rock fracturing or its "ruining" destruction.

Four mechanical characteristics of each lithotype are used for calculation of the massif's SSS: simple compression strength of undisturbed rock, residual rock compression strength (at the stage of "ruining" destruction), the module of rock deformation and its module of decay. If interaction with any bolting system of mine working is investigated, bolting elements materials behavior is also modeled according to the complete diagram of deformation in order to receive more adequate results; for instance, behavior of steel frame support is described taking into account the yield point and the subsequent stage of hardening. It is quite obvious that while modeling the layered massif including a set of lithotypes with significantly different mechanical properties and reflecting parameters of bolting system, the statement of the geomechanical task is extremely difficult, and the necessity to solve it should be thoroughly substantiated.

The physical model of materials (including rock) deformation complete diagram has been used in studying SSS of poor rocks layered massif around in-seam working for the purpose of reseach into the mechanism of rock pressure manifestations development and major factors defining them. A series of multi-variant calculations of SSS in the system "massif - support" has been carried out. One fragment of these calculations is given in Figure 8, which presents two diagrams of stresses intensity $\sigma$ for the same structure of the massif, but at different depths of mine working arrangement. Since the reflection of complete diagrams of rock and bolting materials deformation incorporates step-by-step calculation of final elements grid, the depth $H$ of mine working location smoothly changes within the set range and allows to define rather accurately conditions of the nearby massif (or certain areas) transition into limit and out-oflimit stages of deformation.

The research established that the main factors defining formation of SSS in the system "massif - support" are the ratios of mechanical characteristics of lithotypes and the depth of mine working placement which determines initial geostatic pressure in the undisturbed massif. This can be confirmed by diagrams $\sigma$ in Figure 8: at the depth of $H=200 \mathrm{~m}$ mainly elastic condition practically of all elements of the system "massif - support" takes place; with transition to the depth of $H=600 \mathrm{~m}$, rocks of immediate roof and bottom are not only in the limit, but mostly in out-of-limit state. Here the movements of mine working rock contour are so big (to $2.8 \mathrm{~m}$ in the roof and to $1.8 \mathrm{~m}$ in the bottom) that the rock practically fills all the cavity of a mine working; which is explained by the process of fracturing of a considerable volume of the massif in the vicinity of the roadway.

It is revealed that when out-of-limit state sets in at least one of nearby rock layers, the gradient of displacements growth of a rock contour repeatedly increases and this process becomes a cause of disturbance of operational conditions of mine working. 
(a)

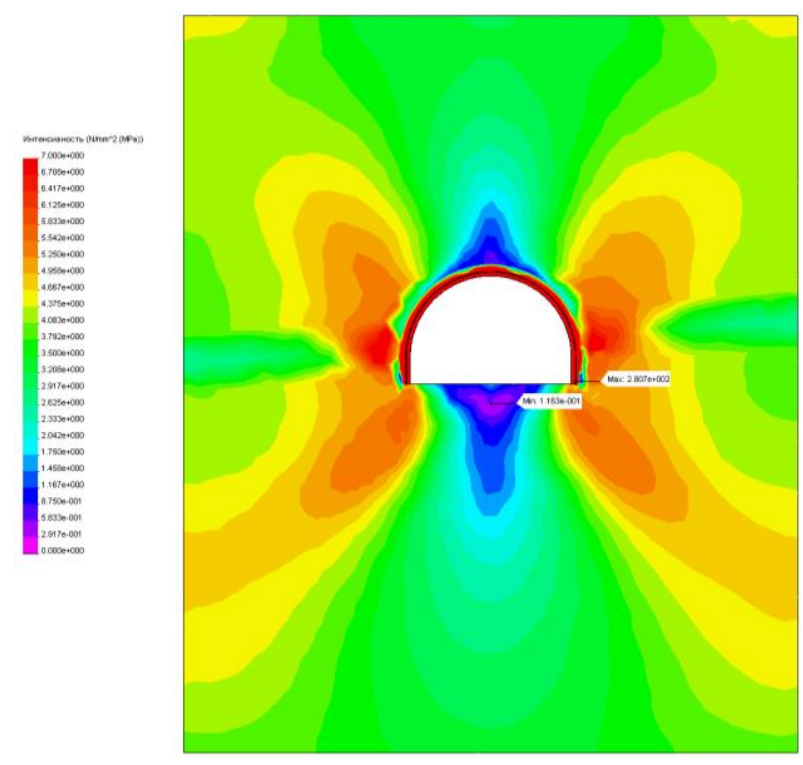

(b)

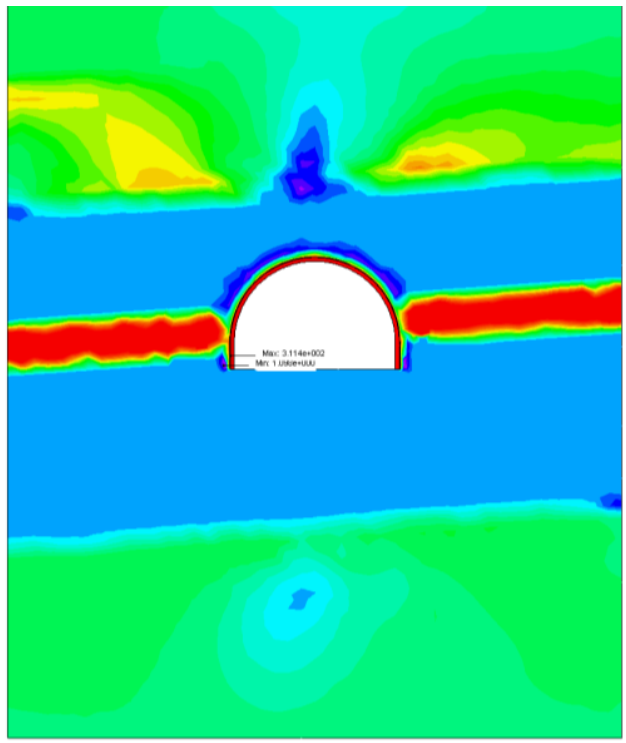

Figure 8. Diagrams of stresses $\sigma$ intensity distribution in foliated massif of poor rocks around in-seam mine working at the depths of $200 \mathrm{~m}(\mathrm{a})$ and $600 \mathrm{~m}(\mathrm{~b})$

The established phenomenon of "boost" in displacements of rock contour is caused by some boundary ratios of strength and deformation characteristics of nearby rock layers, as well as mine working placement depth which demands conducting of special research on their definition within physical model with reflection of the complete diagram of "massif-support" system elements deformation.

A number of the thought-provoking results were received during the conducted research.

Firstly, various combinations of strength and deformation characteristics distribution in each of nearby rock layers cause different extent of their influence on changes of stresses fields and displacements with growth of mine working placement depth. The defining factor is the condition type of nearby rock layers at the concrete size of parameter $H$ : prelimit, limit and out-of-limit.

Secondly, the relation of SSS components of the massif to parameter $H$ becomes nonlinear with setting out of a limit state at least of one of rock layers, and in outof-limit state intensity of displacement growth of the rock contour of a mine working increases manifold, while intensity of stresses - decreases.

Thirdly, sufficient independence of a rock layer stresses field from the condition of neighboring layers is revealed:

- layers of lowered hardness with the growth of $H$ pass into a limit (out-of-limit) state practically irrespectively of strength characteristics of the neighboring harder lithotypes;

- stresses field in harder rock layers hradly depends upon transition of the next layer to a limit state.

Fourthly, SSS of the frame support and regularities of its change with the increase in mine working position depth are in close connection with strength and deformation characteristics of the nearby rock layers, but are nonlinear, especially, upon transition of layers to limit and out-of-limit states. For instance, attenuation of func- tion $\sigma(H)$ growth is caused by emergence and increase in the zones of plastic deformations in metal frame support; this process steadily begins in the lower part of the frame props (they are bent into the working cavity) and extends with the growth of $H$ almost along all the frame contour (except local areas of prelimit state in the dome). Formation of the system of "plastic joints" along the contour of the frame support promotes (in some cases) the development of its deformations which exclude the possibility of mine working further operation.

Thus, we have revealed the effect of the "avalanchetype" growth of displacement typical of rock contour of in-seam mine working placed in layered massif of small hardness rocks; it is conditioned by appearance of certain boundary ratios of geomechanical parameters which cardinally changes SSS of the massif and mechanism of rock pressure manifestations development.

One more important section in problems of geomechanics concerns dealing with rheological properties of rocks which are the defining development factor in time of processes of massif displacement around mine workings of different function.

Studying change regularities of SSS of coal-bearing massif in time of a stoping face break which periodically occurs for the technological reasons and owing to emergencies is of practical interest. During the mine instrumental monitoring, we established some time regularities of displacements development of a rock contour of the extraction roadway interfaced to a longwall, and the growth of load on mechanized support sections in stoping face during the period of its stoppage. The rheological model reflecting an extended site of conjugation of longwall with extraction roadway in space has been constructed for generalization of these discretely received experimental regularities and studying of behavior of massif's extensive area in and around stoping operations conducting. The rheological model of rock behavior is constructed on the basis of ANSYS software which al- 
lowed to obtain values of unknown coefficients of the creeping equation by means of approximation of real diagrams of modeled lithologic differences creeping.

The example of geomechanical processes development in time is shown on diagram of full displacements (Fig. 9) for three discrete values of longwall downtime: $t=0 \mathrm{~h}, t=12 \mathrm{~h}$ and $t=24 \mathrm{~h}$.

(a)

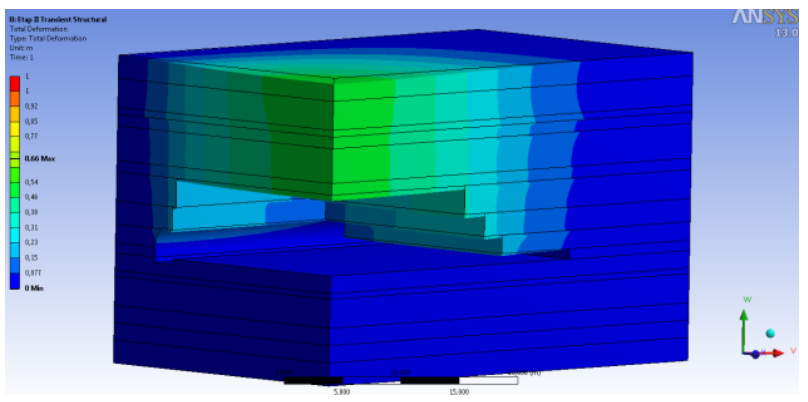

(b)

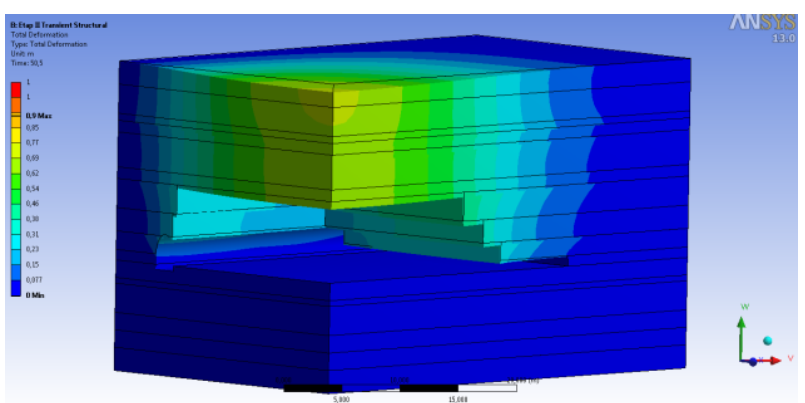

(c)

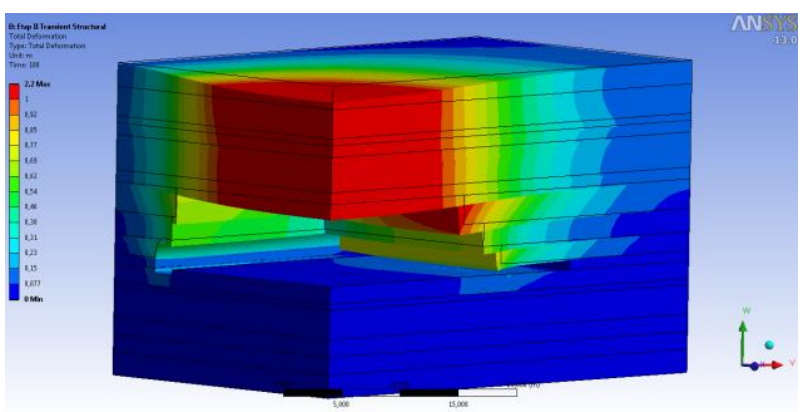

Figure 9. Diagrams of full displacements $U$ in coal-bearing massif near conjugation of longwall with extraction roadway: (a) longwall stopping time $t=0 \mathrm{~h}$; (b) longwall downtime $t=12 \mathrm{~h}$; (c) longwall downtime $t=24 h$

Diagrams of full displacements are characterized by the following features during longwall stoppage $(t=0 \mathrm{~h})$ : in abutment pressure zone ahead the longwall, field $U$ is uniform, the size of displacements is equal to only $70-150 \mathrm{~mm}$. The greatest movements are recorded in the roof over the worked-out area: here on the planes $Y X$ and $Y Z$ there is also a gradual growth of $U$ to values of $460-660 \mathrm{~mm}$ at a distance to $28 \mathrm{~m}$ from the face and to $19 \mathrm{~m}$ from the extraction roadway. These coordinates, taking into account the extracted thickness of the layer and fracturing of collapsed rocks of the immediate roof are characterized by interlocking of falling rocks of the main roof and uncontrolled collapse zones. Here it is necessary to pay attention not only to qualitative, but also to quantitative compliance of the extent of above-the-coal strata lowering in worked-out area with the existing theories of rock pressure.

The longwall stoppage for up to $24 \mathrm{~h}$ very significantly influences the development of full displacements in majority of areas of the studied object (Fig. 9b, c). Lowering of roof rock layers increases moderately - to $150-230 \mathrm{~mm}$ in abutment pressure zone ahead of stoping face. Lowering of roof layers over longwall is much more intensive: displacements $U$ increase from $230-310 \mathrm{~mm}$ at the wall face, to $540-690 \mathrm{~mm}$ around the protection sections of mechanized support; while during further removal from the face, roof lowering increases to $1 \mathrm{~m}$.

Thus, rheological phenomenon which is called creeping deformation actively proceeds during longwall stoppage; it negatively affects the condition of mechanized support sections, creating the danger of the mechanized complex landing onto the "rigid base".

Creeping of massif deformations actively develops also nearby the extraction roadway, especially, in its roof. Here at $t=24 \mathrm{~h}$, displacements increase to $620-800 \mathrm{~mm}$ which already creates a threat to stability of mine working and problems with its operation. Growth of displacements is less intensive in sides of the roadway, nevertheless, they reach $540-620 \mathrm{~mm}$.

In general, an unambiguous conclusion about essential danger (in given mine-and-geological conditions) for stability of the extraction roadway and stoping face of development process of creeping deformations of coalbearing strata follows from the analysis of full displacements diagrams during stoppage of stoping face lasting for more than $12 \mathrm{~h}$.

Following the results of SSS research of the rheological model under study, it is possible to draw a number of conclusions about geomechanical displacement processes of coal-bearing massif nearby extraction roadway and end section of longwall, as well as regularities of time influence of its downtime on stress components changing and displacement:

- vertical stresses $\sigma_{y}$ in anomalous zones are closely related to a longwall downtime $t$ expressed in relaxation of concentrations of compressing $\sigma_{y}$ and reduction in the absolute value of stretching $\sigma_{y}$ which on the whole plays a positive role;

- horizontal stresses $\sigma_{x}$ and $\sigma_{z}$ also show ambiguous tendencies of relation to time $t$ : the ill-defined relaxation of stresses is observed in some areas of the model; there is a growth of functions $\sigma_{x}(t)$ and $\sigma_{z}(t)$ in other areas; components $\sigma_{x}$ and $\sigma_{z}$ have also no essential relation with a longwall downtime $t$ in third areas;

- intensity of stresses $\sigma$ is considerably changing in time $t$, but with opposite tendencies for different types of rocks: for harder and more rigid layers of sandstone, increasing of $\sigma$ in time $t$ is observed; relaxation of $\sigma$ actively develops for weaker and easy-deformed siltstones and mudstones;

- the intensive weakening of roof rocks takes place ahead the longwall at a distance to $6-8 \mathrm{~m}$, which limits 
passage of rock consoles behind mechanized support and partially reduces negative effect of the main roof landing;

- rheological process of creeping deformations which is dangerous in respect to the landing of mechanized support sections on the "rigid base" and difficulties of extraction roadway operation is most brightly shown.

Main conclusion: influence of rheological processes of creeping deformations and stresses relaxation in extensive area of the massif containing end section of stoping face and conjugated extraction roadway is considered; regularities of displacements development of above-thecoal strata stoping face stoppage are generalized.

\section{CONCLUSIONS}

Three groups of numerical solution peculiarities related to geomechanics problems whose reflection in calculation models determines the level of adequacy of the results received during computing experiment are established and substantiated.

It is proved that massif's stratification in calculation model differently influences separate components of stresses, and rock pressure cannot be considered as the function directly proportional to the pillar weight of rocks above mine working. Degree of the received results adequacy is directly connected with reasonable choice of a contact type on the beddings planes of adjacent lithologic differences: rigid contact, contact with slipping, contact with friction force. It is established that application of this or that type of contact leads to essential qualitative and quantitative changes of massif's SSS components distribution.

It is revealed that in geomechanical models which consider massif's fracturing at the macrolevel (geometrical clusters of cracks systems), the distribution pattern of SSS components essentially changes, and the main difficulty consists in ensuring appropriate stability of computing process. For this purpose, it is offered to divide models according to the degree of their complexity on macro - and microlevels in order to receive guaranteed reliable results.

It is established that degree of reliability of geomechanical processes reflection considerably depends upon the reasonable choice of physical model behavior of rock and materials of bolting constructions. It is proved that in the conditions of the predicted appearance of extensive zones of inelastic condition of rock, distinctions in parameters of rock pressure anomalies are estimated in hundreds of percent during comparison of task solution results in elastic and elastic-plastic statements; these differences directly affect the SSS of bolting construction and the choice of its rational parameters.

Degree of adequacy and reliability of computing experiment results essentially depends on objectivity of these processes reflection during probable development of weakening processes and destruction of lithotypes around mine working. Here it is expedient to use the physical model describing complete diagram of rock deformation. It is this model that for the first time allowed to establish the phenomenon of "boost" in shifts of rock contour of mine working caused by some boundary ratios of strength and deformation characteristics of nearby layers and also development of depth placement.
The new step in consideration of geomechanical processes development in time is taken during usage of rheological rock model behavior, because only it allowed to reveal and study regularities of displacement of abovethe-coal strata around conjugation of stoping face and extraction roadway during emergency stoppage of longwall. Rheological process of creeping deformations is shown to form dangerous prerequisites of the landing of mechanized support sections of stoping face on the "rigid base" and exit from an operational condition of extraction roadway is shown.

It is established that complication of geomechanical behavior model of a massif is accompanied by decrease in stability of computing process. Therefore, during computing experiment, it is necessary to look for a compromise between aspiration of the most adequate reflection of a condition of the concrete massif of rocks (including system of mine working's bolting) and a main objective of a solvable task of establishing these or those regularities of rock pressure manifestations.

\section{ACKNOWLEDGEMENTS}

The materials discussed in the article were received while performing a complex of research works at the request of a number of industrial enterprises in coal mining in Donbas. The authors are grateful to M. Illiashov, M. Barabash, Yu. Cherednychenko, O. Vivcharenko, V. Chervatiuk, O. Husiev for providing mine-andgeological and technical information on features of conducting mining operations at their enterprises, and also for useful recommendations and fruitful discussion of the received results which are intended to provide an effective solution to mine-technical issues in coal mining.

\section{REFERENCES}

Bondarenko, V., Kovalevs'ka, I., \& Fomychov, V. (2012). Features of Carrying Out Experiment Using Finite-Element Method at Multivariate Calculation of "Mine Massif Combined Support" System. Geomechanical Processes during Underground Mining, 7-13. http://dx.doi.org/10.1201/b13157-3

Chigarev, A., Kravchuk, A., \& Smalyuk, A. (2004). ANSYS dlya inzhenerov. Moskva: Mashinostroenie.

Coggan, J., Gao, F., Stead, D., \& Elmo, D. (2012). Numerical Modelling of the Effects of Weak Immediate Roof Lithology on Coal Mine Roadway Stability. International Journal of Coal Geology, (90-91), 100-109. http://dx.doi.org/10.1016/j.coal.2011.11.003

Franklin, J., Fraley, J., \& Burnham, R. (1974). Polymeric Materials for Underground Support 2F. US BUR. MINES RI 7836, 1974, 16P. International Journal of Rock Mechanics and Mining Sciences \& Geomechanics Abstracts, 11(8). 168. http://dx.doi.org/10.1016/0148-9062(74)91856-7

Gallager, R. (1984). Metod konechnykh elementov. Moskva: Mir.

Garg, P., \& Jaiswal, A. (2015). Estimation of Modulus of the Caved Rock for Underground Coal Mines by Back Analysis using Numerical Modelling. Journal of The Institution of Engineers (India), 1-5. http://dx.doi.org/10.1007/s40033-015-0097-1

Kovalevska, I., Illiashov, M., Fomychov, V., \& Chervatuk, V. (2012). The Formation of the Finite-Element Model of the System "Undermined Massif - Support of Stope". Geomechanical Processes During Underground Mining, 73-79. http://dx.doi.org/10.1201/b13157-13 
Kuznecov, G., Ardashev, K., \& Filatov, N. (1987). Metody i sredstva resheniya zadach gornoj geomekhaniki. Moskva: Nedra.

Manoj, K. (2010). Design of Support System for Bord and Pillar Workings. Thesis for the degree of bachelor of technology in mining engineering.

Matvienko, Yu. (2006). Modeli i kriterii mekhaniki razrusheniya. Moskva: Fizmatlit.

Prusek, S. (2010). Review of Support Systems and Methods for Prediction of Gateroads Deformation. New Techniques and Technologies in Mining, 25-35. http://dx.doi.org/10.1201/b11329-6

Samarskiy, A. (1989). Chislennye metody. Moskva: Nauka.

Sekulovich, M. (1993). Metod konechnykh elementov. Moskva: Strojizdat.

Shi, L., Liu, Y., \& Wang, S. (2015). Overburden Failure Height and Fissure Evolution Characteristics of Deep Buried, Extra Thick Coal Seam and Fully-Mechanized Caving Mining of China. Proceedings of the 2015 International Conference on Water Resources and Environment (Beijing, 25-28 July 2015), 207-216.

http://dx.doi.org/10.1201/b19079-36
Symanovych, G., Ganushevych, K., \& Chervatyuk, V. (2010). Researches of Influence of Depth of In-Seam Working on Displacement Field of Rocks in Its Vicinity. New Techniques and Technologies in Mining, 121-125. http://dx.doi.org/10.1201/b11329-20

Yu, H., Kong, L., Niu, Z., Zhu, S., \& Jing, D. (2013). Numerical Simulation of Bolt-Mesh-Anchor Support Technology at Soft Rock Roadway. Advanced Materials Research, (868), 251-254. http://dx.doi.org/10.4028/www.scientific.net/amr.868.251

Zenkevich, O., \& Morgan, K. (1986). Konechnye ehlementy $i$ approksimaciya. Moskva: Mir.

Zhang, K., Zhang, G., Hou, R., Wu, Y., \& Zhou, H. (2014). Stress Evolution in Roadway Rock Bolts During Mining in a Fully Mechanized Longwall Face, and an Evaluation of Rock Bolt Support Design. Rock Mechanics and Rock Engineering, 48(1), 333-344. http://dx.doi.org/10.1007/s00603-014-0546-4

Zienkiewicz, O., Taylor, R., \& Zhu, J. (2005). Adaptive Finite Element Refinement. The Finite Element Method Set, 500-524.

http://dx.doi.org/10.1016/b978-075066431-8.50182-x

\section{ABSTRACT (IN UKRAINIAN)}

Мета. Узагальнення досвіду чисельного моделювання методом скінченних елементів геомеханічних процесів навколо гірничих виробок і формування рекомендацій з обгрунтування адекватної будови й поведінки фізичної моделі гірського масиву.

Методика. Для розв’язання задач геомеханіки використані пакети прикладних програм Solidworks Simulation (COSMOS/M) i ANSYS.

Результати. Наведено розв'язання геомеханічних задач з актуальних питань оцінки НДС гірського масиву навколо підземних виробок різного призначення. Отримано закономірності поведінки гірського масиву й надано рекомендації з адекватного й достовірного відображення його текстурних особливостей (шаруватість і тріщинуватість) та фізичної моделі стану гірської породи (пружна, пружно-пластична, реологічна, повна діаграма деформування з урахуванням знеміцнення і розпушення).

Наукова новизна. Отримано низку нових закономірностей розвитку процесів зрушення вуглевміщуючого масиву навколо гірничих виробок з урахуванням його шаруватості й тріщинуватості, граничного й позамежного станів в окремих областях, а також впливу реологічних властивостей гірських порід.

Практична значимість. Комплекс розв'язань геомеханічних задач дозволяє підвищити вірогідність прогнозу проявів гірського тиску й обгрунтувати технічні розв'язання з ефективного й безпечного ведення гірничих робіт на вугільних шахтах.

Ключові слова: гірський масив, підземна виробка, метод скінченних елементів, напруження, деформації, шаруватість, тріщинуватість, фізична модель, гірський тиск

\section{ABSTRACT (IN RUSSIAN)}

Цель. Обобщение опыта численного моделирования методом конечных элементов геомеханических процессов вокруг горных выработок и формирование рекомендаций по обоснованию адекватного строения и поведения физической модели горного массива.

Методика. Для решения задач геомеханики использованы пакеты прикладных программ SolidWorks Simulation (COSMOS/M) и ANSYS.

Результаты. Приведены решения геомеханических задач по актуальным вопросам оценки НДС горного массива вокруг подземных выработок различного назначения. Получены закономерности поведения горного массива и даны рекомендации по адекватному и достоверному отражению его текстурных особенностей (слоистость и трещиноватость) и физической модели состояния горной породы (упругая, упруго-пластическая, реологическая, полная диаграмма деформирования с учетом разупрочнения и разрыхления).

Научная новизна. Получен ряд новых закономерностей развития процессов сдвижения углевмещающего массива вокруг горных выработок с учетом его слоистости и трещиноватости, предельного и запредельного состояния в отдельных областях, а также влияния реологических свойств горных пород.

Практическая значимость. Комплекс решений геомеханических задач позволяет повысить достоверность прогноза проявлений горного давления и обосновать технические решения по эффективному и безопасному ведению горных работ на угольных шахтах.

Ключевые слова: горный массив, подземная выработка, метод конечных элементов, напряжения, деформации, слоистость, трещиноватость, физическая модель, горное давление 


\section{ARTICLE INFO}

Received: 30 March 2016

Accepted: 27 June 2016

Available online: 30 September 2016

\section{ABOUT AUTHORS}

Volodymyr Bondarenko, Doctor of Technical Sciences, Head of the Underground Mining Department, National Mining University, 19 Yavornytskoho Ave., 4/56, 49005, Dnipropetrovsk, Ukraine. E-mail: v_domna@yahoo.com

Monika Hardygora, Doctor of Technical Sciences, Professor of Faculty of Geoengineering, Mining and Geology, Wroclaw University of Technology, 27 Wybrzeże Wyspiańskiego, 50-370, Wroclaw, Poland. E-mail: monika.hardy gora@pwr.wroc.pl

Hennadii Symanovych, Doctor of Technical Sciences, Professor of the Underground Mining Department, National Mining University, 19 Yavornytskoho Ave., 4/58, 49005, Dnipropetrovsk, Ukraine. E-mail: symanovych@nmu.org.ua

Vadym Sotskov, Candidate of Technical Sciences, Associate Professor of the Underground Mining Department, National Mining University, 19 Yavornytskoho Ave., 4/60, 49005, Dnipropetrovsk, Ukraine. E-mail: vadimsockov@ gmail.com Vasyl Snihur, Candidate of Technical Sciences, Director MA “Ternivske”, PJSC “DTEK Pavlohradvuhillia”, 76 Lenina Ave., 51400, Pavlohrad, Ukraine. E-mail: SnigurVG@dtek.com 